\title{
Plant growth promoting traits of psychrotolerant bacteria: A boon for agriculture in hilly terrains
}

\author{
Patni $\mathrm{B}^{1}$, Panwar $\mathrm{AS}^{2}$, Negi $\mathrm{P}^{2}$ and Joshi GK${ }^{2^{*}}$ \\ ${ }^{1}$ HAPPRC, HNB Garhwal University, Srinagar (Garhwal), Uttarakhand, India \\ ${ }^{2}$ Department of Zoology and Biotechnology, HNB Garhwal University, Srinagar (Garhwal), Uttarakhand, India
}

Article history

Received: 14 September 2017 Accepted: 24 December 2017

Published: 05 January 2018

(C) Patni et al. (2018)

Editor

Veena S Anil

Publisher

Horizon e-Publishing Group

Correspondence

G K Joshi

$\bowtie$ gkjoshi@rediffmail.com

\begin{abstract}
Plant growth promoting bacteria (PGPB) are well known to promote plant growth in a number of ways. It is important to study plant growth promoting potential of bacteria capable of growing in extreme environments to establish their role in promoting agricultural yield under harsh conditions. Psychrophilic or psychrotolerant bacteria with plant growth promoting traits may improve the quality of agricultural practices in hilly terrain. The agricultural importance of such microbes stems from the fact that the world over temperate agro-ecosystems are characterized by low temperatures and short growing seasons that subject both plant and microbial life to cold temperature induced stress. Hence, there is a need to identify potential microbes that retain their functional traits under low temperature conditions. Such microbes can be used to enhance the agricultural yields in low temperature areas of the world. This review describes plant growth promoting activities identified in cold adapted bacteria.
\end{abstract}

\section{Keywords}

PGPB; Cold adapted; Bacteria

\section{Citation}

Patni B, Panwar AS, Negi P, Joshi GK. Plant growth promoting traits of psychrotolerant bacteria: A boon for agriculture in hilly terrains. Plant Science Today 2018;5(1):24-28. https://doi.org/10.14719/pst.2018.5.1.352

\section{Introduction}

Bacteria that have the potential to enhance plant growth are commonly known as Plant Growth Promoting Bacteria (PGPB).These PGPB can stimulate plant growth directly or indirectly in a variety of ways. The direct mechanism includes providing elements like nitrogen, phosphorus and essential minerals to plants as well as modulation of the level of phytohormones. On the other hand, indirect mechanisms include prevention or reduction of infection from various phytopathogens to plants (1). A mixture of different PGPB as microbial consortia can also be used as biofertilizers as replacement of chemical fertilizers, pesticides and supplements (2). Most of the PGPB are known to be the inhabitants of rhizosphere hence known as Plant Growth Promoting Rhizobacteria (PGPR). There have been numerous studies reporting the identification and applications of PGPB or PGPR to improve plant growth both at laboratory and field level under ambient environmental conditions. The scope of their use is also extending to areas where cold climatic conditions persist throughout the year and affect the agriculture practices. The study of cold active PGPB is therefore, important for countries like India where a significant proportion of the cultivable land is situated in cold hilly terrain. To 
Table 1. Plant Growth promoting potential of some cold adapted bacteria

\begin{tabular}{|c|c|c|c|c|c|}
\hline $\begin{array}{l}\text { S. } \\
\text { No. }\end{array}$ & PGP Bacteria & $\begin{array}{l}\text { Growth } \\
\text { conditions }\end{array}$ & Functions & Effect on plant growth & $\begin{array}{l}\text { Refer- } \\
\text { ences }\end{array}$ \\
\hline 1 & $\begin{array}{l}\text { Pseudomonas fragi } \\
\text { CS11RH1 (MTCC } \\
\text { 8984) }\end{array}$ & Pot & $\begin{array}{l}\text { Phosphate solubilization, } \\
\text { indole acetic acid (IAA) } \\
\text { and hydrogen cyanide } \\
\text { (HCN) production }\end{array}$ & $\begin{array}{l}\text { Significantly increased the } \\
\text { germination rate, plant biomass and } \\
\text { nutrient uptake of wheat seedlings. }\end{array}$ & (8) \\
\hline 2 & $\begin{array}{l}\text { Pseudomonas sp. } \\
\text { NARs9 (MTCC9002) }\end{array}$ & Glass house & $\begin{array}{l}\text { IAA production and } \\
\text { phosphate solubilization }\end{array}$ & $\begin{array}{l}\text { Enhanced the germination, shoot and } \\
\text { root lengths of wheat seedlings }\end{array}$ & (26) \\
\hline 3 & Pseudomonas sp. & $\begin{array}{l}\text { Culture } \\
\text { dishes }\end{array}$ & $\begin{array}{l}\text { Solubilization of } \\
\text { different sources of } \\
\text { inorganic phosphate }\end{array}$ & $\begin{array}{l}\text { Bacterial inoculation promoted root } \\
\text { development of Deschampsia } \\
\text { antarctica Desv }\end{array}$ & (27) \\
\hline 4 & Pseudomonas sp. & $\begin{array}{l}\text { Pots in green } \\
\text { house }\end{array}$ & & $\begin{array}{l}\text { Bacterization significantly increased } \\
\text { lentil shoot length, root length, root } \\
\text { biomass, and shoot biomass }\end{array}$ & (28) \\
\hline 5 & $\begin{array}{l}\text { Pseudomonas sp. } \\
\text { PGERs17 (MTCC } \\
\text { 9000) }\end{array}$ & Pot & $\begin{array}{l}\text { IAA production, } \\
\text { tricalcium phosphate } \\
\text { solubilization, HCN and } \\
\text { siderophore production. } \\
\text { Exhibited inhibitory } \\
\text { activity against several } \\
\text { phytopathogenic fungi } \\
\text { such as Sclerotium } \\
\text { rolfsii, Rhizoctonia } \\
\text { solani, Pythium sp. and } \\
\text { Fusarium oxysporum }\end{array}$ & $\begin{array}{l}\text { Seed bacterization with the isolate } \\
\text { enhanced the germination of wheat } \\
\text { seedlings with higher root and shoot } \\
\text { lengths. }\end{array}$ & (29) \\
\hline 6 & Pseudomonas sps. & $\begin{array}{l}\text { Pots in glass } \\
\text { house }\end{array}$ & $\begin{array}{l}\text { IAA production, } \\
\text { phosphate } \\
\text { solubilization, HCN and } \\
\text { siderophore production }\end{array}$ & $\begin{array}{l}\text { Significant increase in shoot length, } \\
\text { root length, root biomass, and shoot } \\
\text { biomass of wheat seedling. Bacterial } \\
\text { inoculation significantly increases N, } \\
\text { Fe and nutrient uptake }\end{array}$ & (30) \\
\hline 7 & $\begin{array}{l}\text { Serratia marcescens } \\
\text { SRM (MTCC 8708) }\end{array}$ & Pot & $\begin{array}{l}\text { Phosphate solubilization, } \\
\text { IAA, HCN and } \\
\text { siderophore production }\end{array}$ & $\begin{array}{l}\text { Seed bacterization significantly } \\
\text { enhanced plant biomass and nutrient } \\
\text { uptake of wheat seedlings }\end{array}$ & (31) \\
\hline 8 & $\begin{array}{l}\text { Pseudomonas lurida } \\
\text { M2RH3 (MTCC 9245) }\end{array}$ & Pot & $\begin{array}{l}\text { Phosphate solubilization, } \\
\text { IAA and siderophore } \\
\text { production }\end{array}$ & $\begin{array}{l}\text { Seed bacterization influenced the } \\
\text { growth and nutrient uptake } \\
\text { parameters of wheat seedlings }\end{array}$ & (9) \\
\hline 9 & Pantoea dispersa $1 \mathrm{~A}$ & Pot & $\begin{array}{l}\text { Phosphate solubilization, } \\
\text { IAA, siderophore and } \\
\text { HCN production }\end{array}$ & $\begin{array}{l}\text { Nutrient uptake ability and growth of } \\
\text { wheat seedlings is positively promoted }\end{array}$ & (20) \\
\hline 10 & $\begin{array}{l}\text { Exiguobacterium } \\
\text { acetylicum 1P (MTCC } \\
\text { 8707) }\end{array}$ & $\begin{array}{l}\text { Pots in glass } \\
\text { house }\end{array}$ & $\begin{array}{l}\text { Phosphate solubilization, } \\
\text { IAA, siderophore and } \\
\text { HCN production }\end{array}$ & $\begin{array}{l}\text { Seed bacterization positively } \\
\text { influenced the growth and nutrient } \\
\text { uptake parameters of wheat seedlings. }\end{array}$ & (32) \\
\hline
\end{tabular}

sustain and improve the crop production in hill mountain agro ecosystem, it is imperative to, harness cold adapted strains of bacteria that can positively influence plant growth and development as well as offset the negative influence of cold temperature. This review describes the plant growth promoting traits of various cold adapted bacterial strains recently isolated and studied by different workers.

\section{Nitrogen fixation}

Nitrogen fixing microorganisms make the atmospheric nitrogen available to plants in a form in which it could easily be assimilated by the plants. Verma et al. (3) have reported $\mathrm{N}_{2}$ fixation by various psychrotolerant bacterial species of Arthrobacter, Bacillus, Bordetella, Providencia, Pseudomonas, Acinetobacter and Stenotrophomonas. Among them, the predominant nitrogen fixing species were Bacillus and Pseudomonas. Rhizobia originating from the cooler climates of North America were able to positively affect the nitrogen fixation and nodulation in soybean, compared to their counterparts originating from the warmer southern climes (4). 


\section{Phosphate solubilization}

Phosphorus is one of the most important elements in the nutrition of plants. Although, it is highly abundant in soils in both organic and inorganic forms, a great proportion of it being in the insoluble, immobilized and precipitated form, is hardly of any use to the plants. PGP bacteria can solubilize and mineralise inorganic phosphorus or facilitate the mobility of organic phosphorus through microbial turnover and/or increase the root system (5). Das et al.(6) first reported $\mathrm{P}$ solubilization at low temperature by cold tolerant Pseudomonas at 10 and $25^{\circ} \mathrm{C}$. A cold tolerant phosphate solubilizing and antagonistic strain of Pseudomonas putida was reported to be isolated from a sub-alpine location of central Himalayas by Pandey et al. (7). The strain could solubilize phosphate in the temperature range of $4-28^{\circ} \mathrm{C}$. Phosphate solubilization by a cold tolerant strain of Pseudomonas fragi was reported by Selvakumar et al. (8). The strain solubilized phosphate in the temperature range of $4-30^{\circ} \mathrm{C}$ and also significantly increased the germination rate, plant biomass and nutrient uptake of wheat seedling at low temperature. A psychrotolerant bacterial strain Pseudomonas lurida M2RH3 was isolated from Himalayan region and shown to exhibit phosphate solubilization activity by Selvakumar et al. (9). In a separate investigation four cold adapted phosphate solubilizing PGPR were isolated from the root nodules of pea by Meena et al. (10).

Potassium solubilization: Potassium (K) is also a major essential macronutrient required by plants for proper growth. The concentration of soluble potassium in soil is usually very low and more than $90 \%$ of potassium in soil exists in the form of insoluble rocks and silicate minerals (11). Nine psychrotolerant bacterial strains with capabilities to solubilize potassium were isolated and identified by Verma et al. (3) from northern hills zone of India.

\section{Siderophore production}

Iron is an essential growth cofactor for living organisms. For the soil microorganisms, availability of solubilized ferric ion in soils is limited at neutral and alkaline $\mathrm{pH}$. Siderophore producing plant growth promoting rhizobacteria can prevent the proliferation of pathogenic microorganisms by sequestering $\mathrm{Fe}^{3+}$ in the area around the root (12). These siderophores bind with ferric ion and make siderophore-ferric complex which subsequently binds with specific receptors at the bacterial cell surface. Siderophores have been implicated for both direct and indirect enhancement of plant growth by rhizospheric microorganisms (13). Siderophores provide an advantage in survival of both plants and bacteria because they meditate competition that results in removal of phytopathogens and other microbial competitors in the rhizosphere by reduction in the availability of iron for their survival (14-15). Katiyar and Goel (16) reported a cold tolerant mutant of Pseudomonas fluorescens causing significant increase in siderophore production and rhizosphere colonization. A cold tolerant bacterium Azotobacter chroococcum was isolated and examined for siderophore production by Rajaee et al.(17). Selvakumar et al. (9) have also reported siderophore production by the psychrotolerant bacterial strain Pseudomonas lurida M2RH3. On the other hand, Verma et al. (3) have identified as many as 35 bacterial strains with potential of siderophore production to varying extent. In another study, seven bacterial strains isolated from glacial ice by Balcazar et al. (18) were tested positive for siderophore production.

\section{Phytohormone production}

Plant growth promoting rhizobacteria produce phytohormones that can affect cell proliferation in the root architecture by over production of lateral roots and root hairs with a subsequent increase of nutrient and water uptake

\section{a) Indole-3 -acetic acid (IAA) production}

The auxin, indole-3-acetic acid is an important phytohormone produced by PGPB and treatment with auxin-producing rhizobacteria has been shown to increase the plant growth (19). Many bacterial species have been isolated from cold environmental capable of producing IAA at low temperature. Selvakumar et al. (20) described the plant growth promoting potential of cold tolerant bacterial strains Pantoea dispersa IA and Serratia marcescens SRM isolated from North Western (N.W.) Indian Himalayas. These strains retain their IAA producing abilities at 4 and $15^{\circ} \mathrm{C}$. Meena et al. (10) have reported 4 cold tolerant bacterial isolates producing phytohormone IAA in the range of 62.7$198.1 \mu \mathrm{g} / \mathrm{ml}$. As many as 54 different bacterial strains belonging to the phyla of Firmicutes, Actinobacteria, Bacteriodetes and $\alpha, \beta$ and $Y$ Proteobacteria were isolated from cold deserts of north western Himalayas and found to be associated with IAA production abilities (21). Yadav et al. (22) have documented IAA production from several cold adapted bacteria isolated from cold desert of Leh Ladakh, India. Kumar et al. (23) evaluated a psychrotolerant Pseudomonas jesenii strain MP1 for relative plant growth promoting potential against native Cicer arietinum (L.)., Vigna mungo (L.) Hepper; Vigna radiata (L.) Wilczek., Cajanus cajan (L.) Millsp. and Eleusine coracana (L.) Gaertn and the strain was found to produce IAA. In another study, five bacterial strains producing IAA were reported to be isolated from glacial ice by Balcazar et al. (18).

b) Gibberelic acid: Twenty gibberelic acid producing bacterial strains were isolated and 
identified from the cold desert of Himalayan region by Yadav et al. (21). In another study, Yadav et al. (22) have reported and identified 11 psychrotrophic bacterial strains producing gibberelic acid. More than two dozens of wheat allied psychrotolerant bacterial strains producing gibberelic acid were isolated by Verma et al. (3) from northern hills of India.

\section{HCN production}

Hydrogen Cyanide (HCN) is commonly produced by plant growth promoting bacteria that negatively affect root metabolism and root growth and provides a mechanism for biological control of weeds (24). A total number of 31 representative psychrotolerant bacterial strains were reported to produce HCN by Verma et al. (3). Two psychrotolerant bacterial strains with nearest $16 \mathrm{~S}$ rRNA sequence homology to Pseudomonas sp. were isolated from glacial ice and reported to produce HCN by Balcazar et al. (18). Yadav et al. (21) reported HCN production by 8 bacterial strains while doing prospecting work in the cold desert in north western Himalayas.

\section{ACC deaminase production}

Plant hormone, ethylene is known to influence the growth and development of plants. The ACC deaminase enzyme regulates the concentration of ethylene and can thus reduce the stress-induced ethylene mediated negative impact on plants. A psychrotolerant ACC deaminase producing bacterium $P$. putida UW4 was reported to promote canola plant growth at low temperature under salt stress (25). A total number of 25 representative psychrotolerant bacterial strains were identified as ACC deaminase producers by Verma et al. (3). Yadav et al. (21) also reported ACC deaminase activity by 21 bacterial strains at $4^{\circ} \mathrm{C}$.

\section{Effect of PGPB treatment on Plant growth}

For plants, bacterial inoculation or seed bacterization with PGPB may result in the increased root or shoot development, enhanced percentage seed germination and nutrient uptake rate, more biomass etc. Cold active bacteria can also exert the similar effects on plants by direct or indirect mechanisms. Table 1 summarizes the PGP activities and effect of the treatment of some psychrotolerant bacteria on plant growth as documented by various workers in last decade.

\section{Conclusion}

Hill and mountain agro ecosystems are characterized by difficult terrain, inadequate infrastructure, low input applications and societies entrenched in severe top soil erosion sites. Investments in hill agriculture can become more profitable, particularly in areas where major part of the crop season is characterized by cold temperatures, by the applications of cold tolerant microbial inoculants.Overall, PGPB are excellent model systems which can provide the scientists with novel genetic constituents and bioactive chemicals having diverse uses in agriculture sector and sustainable environment. It is evident from the literature cited in this article that the cold environments are ideal habitats for numerous cold adapted bacteria with plant growth promoting potential. However, their full potential for any commercial use as biofertilizers to improve hill agriculture productivity is to be harnessed in coming years. Future research is required in understanding the PGPB diversity, colonization ability and identification of potential microbes that retain different functional traits under low temperature conditions in the field.

\section{Author's contributions}

NP initiated the work and helped in manuscript writing. PB, PAS and JGK contributed in manuscript writing and corrections.

\section{Acknowledgements}

The authors thank the HOD, Department of Zoology \& Biotechnology and Director, HAPPRC, HNB Garhwal University, Srinagar (Garhwal) for providing the necessary facilities.

\section{Competing Interest}

The authors have declared that there are no competing interests.

\section{References}

1. Ahemad M, Kibret M. Mechanisms and applications of plant growth promoting rhizobacteria: Current perspective. J Kind Saud University-Science. 2014; 26(1):1-20. https://doi.org/10.1016/j.jksus.2013.05.001

2. Minorsky P V (2008) On the inside. Plant Physiology. 146: 323-324. https://doi.org/10.1104/pp.104.900246.

3. Verma P, Yadav AN, Khannam KS, Panjiar N, Kumar S, Saxena AK, Suman A. Assessment of genetic diversity and plant growth promoting attributes of psychrotolerant bacteria allied with wheat (Triticum aestivum) from the northern hills zone of India. Ann Microbiol. 2015;65(4):1885-99.

4. Zhang H, Prithiviraj B, Charles TC, Driscoll BT, Smith DL. Low temperature tolerant Bradyrhizobium japonicum strains allowing improved nodulation and nitrogen fixation of soybean in a short season (cool spring) area. $\quad$ Eur J Agron. 2003; 19(2): 20513. https://doi.org/10.1016/S1161-0301(02)00038-2

5. Richardson AE, Simpson RJ. Soil microorganisms mediating phosphorus availability. Plant Physiology. 2011;156:989-96.

6. Das K, Katiyar V, Goel R. P solubilization potential of plant growth promoting Pseudomonas mutants at low temperature. Microbiol Res. 2003;158(4):359-62. https://doi.org/10.1078/0944-5013-00217

7. Pandey A, Trivedi P, Kumar B, Palni LM. Characterization of a phosphate solubilizing and antagonistic strain of Pseudomonas putida (B0) isolated from a sub-alpine location in the Indian Central Himalaya. Curr Microbiol. 2006;53:102-7. 
8. Selvakumar G, Joshi P, Nazim S, Mishra P, Bisht J, Gupta H. Phosphate solubilization and growth promotion by Pseudomonas fragi CS11RH1 (MTCC 8984), a psychrotolerant bacterium isolated from a high altitude Himalayan rhizosphere. Biologia 2009;64(2):239-45. https://doi.org/10.2478/s11756-0090041-7

9. Selvakumar G, Joshi P, Suyal P, Mishra PK, Joshi GK, Bisht JK, Bhatt JC and Gupta HS.. Pseudomonas lurida M2RH3 (MTCC 9245), a psychrotolerant bacterium from the Uttarakhand Himalayas, solubilizes phosphate and promotes wheat seedling growth. World J Microbiol Biotechnol. 2011;27(5):1129-35.

10. Meena RK, Singh RK, Singh NP, Meena SK, Meena VS. Isolation of low temperature surviving plant growth-promoting rhizobacteria (PGPR) from pea (Pisum sativum L.) and documentation of their plant growth promoting traits. Biocatal Agric Biotechnol. 2015;4(4):806-1.

https://doi.org/10.1016/j.bcab.2015.08.006

11. Parmar P, Sindhu SS. Potassium solubilization by rhizosphere bacteria: influence of nutritional and environmental conditions. Journal of Microbiology Research. 2013;3(1):25-31. https://doi.org/10.5923/j.microbiology.20130301.04

12. Mehnaz S. Secondary metabolites of Pseudomonas aurantiaca and their role in plant growth promotion. In Plant Microbe Symbiosis: Fundamentals and Advances 2013 (pp. 373-393). Springer India.

13. Neilands JB. Microbial iron compounds. Annu Rev Biochem. 1981; 50(1):715-31 https://doi.org/10.1146/annurev.bi.50.070181.003435

14. Masalha J, Kosegarten H, Elmaci O, Mengel K. The central role of microbial activity for iron acquisition in maize and sunflower. Biol Fertil Soils. 2000;30(5):433-9.

15. Wang C, Knill E, Defago G Effect of transferring 1aminocyclopropane-1-carboxylic acid(ACC) deaminase genes into Pseudomonas fluorescens strain $\mathrm{CHAO}$ and its gac A derivative CHA96 on their growth-promoting and disease-suppressive capacities. Can J Microbiol. 2000;46(10):898-7. https://doi.org/10.1139/w00-071

16. Katiyar V, Goel R. Siderophore mediated plant growth promotion at low temperature by mutant of fluorescent pseudomonad. Plant Growth Regul. 2004;42(3):239-44.

17. Rajaee S, Alikhani HA, Raiesi F. Effect of plant growth promoting potentials of Azotobacter chroococcum native strains on growth, yield and uptake of nutrients in wheat JWSS-Isfahan University of Technology. 2017;11(41):285-97.

18. Balcazar W, Rondon J, Rengifo N, Ball MM, Melfo A, Gomez W, Yarzabal LA. Bioprospecting glacial ice for plant growth promoting bacteria. Microbiol $\quad$ Res. 2015;177:1-7. https://doi.org/10.1016/j.micres.2015.05.001

19. Patten CL, Glick BR. Role of Pseudomonas putida in indole acetic acid and development of the host plant root system. Appl Environ Microbiol. 2002;68(8):3795-1.

20. Selvakumar G, Kundu S, Joshi P, Nazim S, Gupta AD, Mishra PK, Gupta HS. Characterization of a coldtolerant plant growth-promoting bacterium Pantoea dispersa $1 \mathrm{~A}$ isolated from a sub-alpine soil in the North Western Indian Himalayas. World J Microbiol Biotechnol. 2008;24(7):955-60.

21. Yadav AN, Sachan SG, Verma P, Saxena AK. Prospecting cold deserts of north western Himalayas for microbial diversity and plant growth promoting attributes. J Biosci Bioeng. 2015A; 119(6): 68393. https://doi.org/10.1016/j.jbiosc.2014.11.006

22. Yadav AN, Sachan SG, Verma P, Tyagi SP, Kaushik R, Saxena AK. Culturable diversity and functional annotation of psychrotrophic bacteria from cold desert of Leh Ladakh (India). World J Microbiol Biotechnol. 2015B; 31(1):95-8. https://doi.org/10.1007/s11274-014-1768-Z

23. Kumar S, Suyal DC, Dhauni N, Bhoriyal M, Goel R. Relative plant growth promoting potential of Himalayan Psychrotolerant Pseudomonas jesenii strain MP1 against native Cicer arietinum (L.)., Vigna mungo (L.) Hepper; Vigna radiata (L.) Wilczek., Cajanus cajan (L.) Millsp. and Eleusine coracana (L.) Gaertn. Afr J Microbiol Res. 2014;8(50):3931-43.

24. Kamei A, Dolai AK, Kamei A. Role of Hydrogen Cyanide Secondary Metabolite of Plant Growth Promoting Rhizobacteria as Biopesticides of Weeds. Global J Sci Front Res. 2014;14(6):109-12.

25. Cheng Z, Park E, Glick BR. 1-Aminocyclopropane-1carboxylate (ACC) deaminase from Pseudomonas putida UW4 facilitates the growth of canola in the presence of salt. Can J Microbiol. 2007; 53(7):912-8. https://doi.org/10.1139/W07-050

26. Mishra PK, Mishra S, Bisht SC, Selvakumar G, Kundu S, Bisht JK, Gupta HS. Isolation, molecular characterization and growth-promotion activities of a cold tolerant bacterium Pseudomonas sp. NARs9 (MTCC9002) from the Indian Himalayas. Biol Res. 2009;42(3):305-13. https://doi.org/10.4067/S0716-97602009000300005

27. Berrı' os G, Cabrera G, Gidekel M, Gutie' rrez-Moraga A. Characterization of a novel antarctic plant growth-promoting bacterial strain and its interaction with Antarctic hair grass (Deschampsia antarctica Desv). Polar Biol. 2012;36(3), 349-2. https://doi.org/10.1007/s00300-012-1264-6.

28. Bisht SC, Mishra PK, Joshi GK. Genetic and functional diversity among root associated psychrotrophic Pseudomonad's isolated from the Himalayan plants. Arch Microbiol. 2013;195(9): 605-5.

29. Mishra PK, Mishra S, Selvakumar G, Bisht SC, Bisht JK, Kundu S, Gupta HS. Characterisation of a psychrotolerant plant growth promoting Pseudomonas sp. strain PGERs17 (MTCC 9000) isolated from North Western Indian Himalayas. Annals of Microbiology. 2008;58(4):561-8.

30. Mishra PK, Bisht SC, Ruwari P, G Selvakumar, Joshi GK, Bisht JK, Bhatt JC, Gupta HS. Alleviation of cold stress in inoculated wheat (Triticum aestivum L.) seedlings with psychrotolerant Pseudomonads from NW Himalayas Arch Microbiol. 2011;193(7):497-13.

31. Selvakumar G, Mohan M, Kundu S, Gupta AD, Joshi P, Nazim S, Gupta HS. Cold tolerance and plant growth promotion potential of Serratia marcescens strain SRM (MTCC 8708) isolated from flowers of summer squash (Cucurbita pepo). Lett Appl Microbiol. 2008;46(2):171-5.

https://doi.org/10.1111/j.1472-765X.2007.02282.x

32. Selvakumar G, Kundu S, Joshi P, Nazim S, Gupta AD, Gupta HS. Growth promotion of wheat seedlings by Exiguobacterium acetylicum 1P (MTCC 8707) a cold tolerant bacterial strain from the Uttarakhand Himalayas. Indian J Microbiol. 2010;50(1):50-6. 